\title{
ANOT CÜRUFLARINDAN BAKIRIN GERİ KAZANIMINDA DÜŞÜK ERIME NOKTALI ÇÖZÜCÜ KULLANIMININ ARAŞTIRILMASI
}

\author{
Mehmet Ali TOPÇU ${ }^{1 *}$, Aydın RÜŞEN ${ }^{2}$ \\ ${ }^{1}$ Karamanoğlu Mehmetbey Üniversitesi, Mühendislik Fakültesi, Metalurji ve Malzeme Mühendisliği Bölümü, Karaman \\ ORCID No : https://orcid.org/0000-0002-0007-5665 \\ ${ }^{2}$ Karamanoğlu Mehmetbey Üniversitesi, Mühendislik Fakültesi, Metalurji ve Malzeme Mühendisliği Bölümü, Karaman \\ ORCID No : https://orcid.org/0000-0001-5592-1411
}

\begin{tabular}{|c|c|}
\hline Anahtar Kelimeler & Öz \\
\hline $\begin{array}{l}\text { Düşük erime noktalı } \\
\text { çözücüler, } \\
\text { Anot Cürufu } \\
\text { Geri Kazanım } \\
\text { Hidrometalurji }\end{array}$ & $\begin{array}{l}\text { Bu çalışmada, ikincil kaynaklardan bakır tel üretimi yapan bir firmadan temin edilen } \\
\text { bakır anot cürufundan bakır geri kazanımı için çevre ve insan sağlığına duyarlı düşük } \\
\text { erime noktalı çözücü kullanımı araştırılmıştır. Bakır anot cürufunun fiziksel, kimyasal ve } \\
\text { mineralojik karakterizasyonu öncesinde yapılan öğütme işleminde cürufiçindeki metalik } \\
\text { bakırın bir kısmı fiziksel olarak ayrılmıştır. Liç deneylerinde son yıllarda hidrometalurjik } \\
\text { süreçlerde kullanılan kolin klorür (ChCl) ve üre (1:2) ile hazırlanan düşük erime noktalı } \\
\text { solvent çevre duyarlı çözücü olarak kullanılmıştır. Liç deneylerinin sonuçlarına göre } \\
\text { fiziksel olarak anot cürufundan ayrılmayan bakır } 72 \text { saatlik reaksiyon süresi, } 95 \text { oC'lik liç } \\
\text { sıcaklığı ve 1/20 katı/sıvı oranı şartlarındaki liç işlemi ile \%90 üzerinde ekstrakte } \\
\text { edilmiştir. Liç deneylerinden sonrasında çözeltideki demir çözünürlügünün oldukça } \\
\text { düşük seviyede kaldığı görülmüşür. Çalışmada elde edilen sonuçlara göre fiziksel olarak } \\
\text { ayırma ve sonrasında ChCl-üre karışımıla hazırlanan düşük erime noktalı çözücü } \\
\text { kullanılarak yapılan liç işlemleri ile bakır anot cürufundan bakır geri kazanımı için } \\
\text { çevreci bir çözücü adayı olabileceği ortaya konmuștur. }\end{array}$ \\
\hline
\end{tabular}

\section{INVESTIGATION OF USE OF DEEP EUTETIC SOLVENT ON COPPER RECOVERY FROM COPPER ANODE SLAG}

\begin{tabular}{l}
\hline Keywords \\
\hline Deep eutetic solvent, \\
Anode slag, \\
Recovery \\
Hydrometallurgy
\end{tabular}

\section{Abstract}

In this study, a deep eutectic solvent which is sensitive to environmental and human health was used for copper recovery from copper anode slime. Metallic copper was obtained after grinding process which performed before leaching experiments and physical, chemical and mineralogical characterization of copper anode slag. In the leaching experiments, a deep eutectic solvent prepared with choline chloride and urea (1:2) that used in hydrometallurgical processes in recent years was used as environmentally sensitive solvent. According to the results of the leaching experiments, copper, which is not separated from the anode slag mechanically, was extracted as approximately $90 \%$ after the leaching test performed at 72 hours of reaction time, $95^{\circ} \mathrm{C}$ of reaction temperature and 1/20 of solid/liquid ratio. After all the leaching experiments, iron solubility remained very low. As result of this work, it has been demonstrated that physical separation and leaching with deep eutectic solvent can be used as an environmentally friendly process for copper recovery from copper anode slag.

Araştırma Makalesi
BaşvuruTarihi
Kabul Tarihi

: 07.10 .2020
$: 25.11 .2020$

$\begin{array}{ll}\text { Research Article } & \\ \text { Submission Date } & : 07.10 .2020 \\ \text { Accepted Date } & : 25.11 .2020\end{array}$

\section{Giriş}

Bakır sahip olduğu üstün fiziksel özellikleri nedeniyle binlerce yıldır kullanılan önemli bir demir dışı metaldir. Son yıllarda artan teknolojik gelişmeler bakıra olan ihtiyacı arttırmış olduğundan bu artan taleple birlikte yüksek tenörlü cevherlerin rezervleri giderek azalmaktadır. Günümüzde metalik bakırın çoğu genellikle sülfürlü cevherlerden zenginleștirme, eritme, dönüştürme ve saflaştırma aşamalarını içeren pirometalurjik yöntemlerle üretilir (Topçu, Rüşen ve Derin, 2019). Bakır cevherlerinden pirometalurjik yöntemle bakır üretiminde ortaya çıkan bakır cürufları demir oksit-silisyum oksit (fayalit), alüminyum oksit,

\footnotetext{
* Sorumlu yazar; e-posta : topcumali@kmu.edu.tr
} 
kalsiyum oksit gibi bileşenlerle birlikte oldukça fazla miktarda bakır, çinko ve nikel gibi elementlerin farklı formlarını da içermektedir. Her bir ton bakır üretimi için yaklaşık olarak 2,2 ton cüruf meydana geldiği ve her yıl dünya genelinde bakır üretiminden yaklaşık 26,4 milyon ton cüruf üretildiği tahmin edilmektedir. Bu nedenle bakır ikincil atıklarının (cürufların) bakır üretimi için değerlendirilmesi çevresel riskler ve ekonomik kayglar nedeniyle önem arz etmektedir (Gorai ve Jana, 2003;Agrawal, Kumari ve Sahu, 2009). Günümüze kadar, hidrometalurjik veya pirometalurjik yöntemler kullanarak bakır cüruflarından değerli metallerin geri kazanılması üzerine birçok çalışma gerçekleştirilmiştir. Bakır cüruflarının değerlendirilmesinde hidrometalurjik yöntemler pirometalurjik yöntemlere göre nispeten daha ekonomik ve çevreci olmasından dolayı sıklıkla kullanılmaktadır. Günümüze kadar, hidrometalurjik yöntemle bakır cüruflarından yapılan geri kazanım işlemlerinde sülfürik asit (Arslan ve Arslan, 2002; Boyrazll, Altundoğan ve Tümen, 2006) HCl (Xiang, Huang, Lv ve Bai, 2017; Chen, Han ve Wang; 2012) , $\mathrm{HNO}_{3}$ (Lee, Kim ve Shin, 2015), $\mathrm{H}_{2} \mathrm{O}_{2}$ (Banza, Gock ve Kongolo, 2002; Turan ve diğ. 2017) basınçlı asit liçi (Li, Papangelakis ve Perederiy, 2009) ve amonyak liçi (Nadirov, Syzdykova, Zhussupova ve Usserbaev, 2013; Roy, Sarkar, Datta ve Rehani, 2015) gibi çözücüler sıklıkla kullanılmıştır. Hidrometalurji yönteminde kullanılan asit-baz kaynaklı çözücülerin insan ve çevre sağlığı üzerindeki olumsuz etkileri nedeniyle hidrometalurjik süreçlerde kullanılabilecek çevre duyarlı çözücüler için birçok çalışma gerçekleştirilmiştir. Geleneksel çözücülerin olumsuz etkileri göz önüne alınarak, daha çevreci çözücü arayışına giren bilim insanları farklı metalürjik atıklardan (ikincil kaynaklarından) metallerin geri kazanımı için imidazolyum temelli iyonik sıvıların kullanımını araştırmışlardır (Whitehead, Zhang, Pereira, McCluskey ve Lawrance, 2007; Dong, Hua, Zhang ve Zhou, 2009; Huang, Chen, Chen, Chen ve Sun, Q, 2014; Rüşen ve Topçu, 2017a). İyonik sıvıların ihmal edilebilir buhar basıncı, geleneksel çözücülere nazaran daha iyi olan termal kararlılığı ve yüksek iletkenliği gibi benzersiz özellikleri hidrometalurjik süreçler için uygun bir ortam sağlamasına rağmen, zayıf biyolojik bozunabilirlikleri, toksik olmaları ve yüksek maliyetleri nedeniyle bu doğrultudaki kullanımlarını sınırlamaktadır. (Zhang Vigier, Royer ve Jerome, 2012; Dai, Van Spronsen, Witkamp, Verpoorteve Choi, 2013) İyonik sıvıların sahip olduğu termal kararlılık, yüksek iletkenlik vb. olumlu özellikleri bünyesinde barındırmakla birlikte düşük maliyet ve yüksek biyobozunurluk gibi özelliklere sahip olmaları nedeniyle düşük erime noktalı çözücülerin hidrometalurjik alanda liç ajanı olarak kullanılabilirliği son yıllarda araştırılmaya başlanmıştır. (Abbott. Capper, Davies, Rasheed ve Tambyrajah, 2003) Düşük erime noktalı çözücüler (DES), ötektik karışım oluşturmak için hidrojen bağı etkileşimi ile birbirleriyle ilişkilendirilebilen genellikle iki veya üç ucuz ve güvenli bileşenlerden oluşur. Oluşturulan DES'lerin erime noktası, her bileşenin erime noktasından daha düşüktür. Genellikle, DES'ler donma noktası aşırı düşürülmesi ile karakterize edilir. DES'lerin birçoğu oda sıcaklığı ile 70 ${ }^{\circ} \mathrm{C}$ arasında sıvı formda bulunmaktadır. $\mathrm{Bu}$ da onları hidrometalurji alanında liç ajanı olarak kullanılabilmesi için iyi bir aday yapmaktadır. Birçok durumda, DES'ler metal tuzları ile dörtlü amonyum tuzu veya dörtlü amonyum tuzunun halojenür anyonu ile kompleks oluşturabilme yeteneğine sahip hidrojen bağ sağlayıcısı (hydrogen böndü donor, HBD) ile elde edilirler (Abbott, Boothby, Capper, Davies ve Rasheed, 2004; Zhang ve diğ., 2012; Paiva ve diğ. 2014). Amonyum tuzları arasında $\mathrm{ChCl}$, düşük maliyeti, biyo-uyumluluğu (biyolojik olarak parçalanabilir) ve düşük toksitesi nedeniyle üre, gliserol, karbonhidrat türevi polioller ve yenilenebilir kaynaklı karboksiler asitler gibi ucuz ve güvenli HBD’ler ile ötektik karışım oluşturmak için sıklıkla kullanılan organik tuzdur (Abbott, Capper, Davies ve Shikotra, 2006b; Zhang ve diğ., 2012).

Bugüne kadar DES’lerin çözme özellikleri, suda çözünen ve çözünmeyen inorganik metal tuzlar, aromatik asitler ve amino asitler gibi birçok alanda ilgi çekici hale gelmiştir (Abbott ve diğ., 2003). İlk defa Abbott ve diğ., (2003) tarafından gerçekleştirilen bir çalışmada, kolin klorür ve üre ile hazırlanan düşük erime noktalı çözücü içerisinde $50{ }^{\circ} C^{\prime}$ 'de metal oksitlerin çözünürlükleri araştırılmıştır. Bu çalışmada, kolin klorür ve çeşitli hidrojen bağ donörleri ile hazırlanan farklı düşük erime noktalı çözücüler içerisinde $\mathrm{CuO}, \mathrm{Cu}_{2} \mathrm{O}, \mathrm{PbO}, \mathrm{ZnO}, \mathrm{Fe}_{2} \mathrm{O}_{3}$, $\mathrm{Fe}_{3} \mathrm{O}_{4}$ gibi farklı metal oksitlerin çözünürlükleri araştırılmıştır (Abbott ve diğ., 2004; Abbott, Capper, Davies, Rasheed ve Shikotra, 2005; Abbott, Capper, Davies ve Shikotra, 2006a). Çeşitli metal oksitlerin farklı düşük erime noktalı çözücüler içerisindeki çözünürlüklerinin ortaya çıkarılması hidrometalurji alanında yeni çalışmaları da beraberinde getirmiştir. Düşük erime noktalı çözücülerin metal oksitleri çözebilme yeteneklerini göz önünde bulunduran araştırmacılar, elektrik ark ocağı tozu, çinko liç atıkları gibi çeşitli metal kaynaklarından $\mathrm{Pb}, \mathrm{Zn}$ ve $\mathrm{Fe}$ gibi metallerin geri kazanımı üzerine çalışmalar gerçekleştirmişlerdir. (Abbott ve diğ., 2009; Rüşen ve Topçu, 2017b, Bakkar, 2014)

Yukarıdaki bilgiler ışı̆̆ı altında, bu çalışmada kolin klorür ve üre karıșımıyla hazırlanan düșük erime noktalı çözücülerin kullanımıyla bakır anot cürufundan bakır geri kazanımı hedeflenmiştir. Ayrıca bu çalışma kapsamında liç deneylerinde kullanılan bakır ikincil atıkların kimyasal ve mineralojik karakterizasyonu da gerçekleştirilmiştir. 


\section{Materyal ve Metot}

\subsection{Materyal}

$\mathrm{Bu}$ çalışma etik kurul kararı gerektiren bir çalışma değildir. Çalıșma bir kurumda yapılan uygulamayı kapsamamaktadır. Ayrıca araştırma ve yayın etiğine de uyulmuştur.

$\mathrm{Bu}$ çalışma kapsamında deneylerde kullanılan anot cürufu İzmit-Gebze'de faaliyetlerini sürdüren Sarkuysan Elektrolitik Bakır Sanayi ve Ticaret A.Ş.'den temin edilmiştir. Kayaç halinde temin edilen anot cürufunun kimyasal analizinin yapılabilmesi amacıyla öncelikle kırma ve öğütme işlemlerine tabi tutularak tane boyutu küçültülmüştür. İlk olarak, yaklaşık 10-15 $\mathrm{cm}$ aralığındaki büyük parçalar çekiç kullanılarak 1 cm'nin altındaki boyutlara indirilmiștir. Daha sonra öğütme işlemi Retsch marka PM100 model bilyeli eksenel değirmende 300 devir/dk karıștırma hızında 1 dakika boyunca ögütülerek homojen boyuta getirilmiştir ve daha ince boyutlu taneler elde edilmiştir. Kırma ve ögütme ișlemlerinden sonra numune boyutları Şekil 1'de gösterilmiştir. Şekil 1.a'da görüldüğü üzere anot cürufunun ihtiva ettiği bakır parçacıkları 1 numara ile kodlanmış, silisyum dioksit fazı ise 2 numara ile işaretlenmiştir.
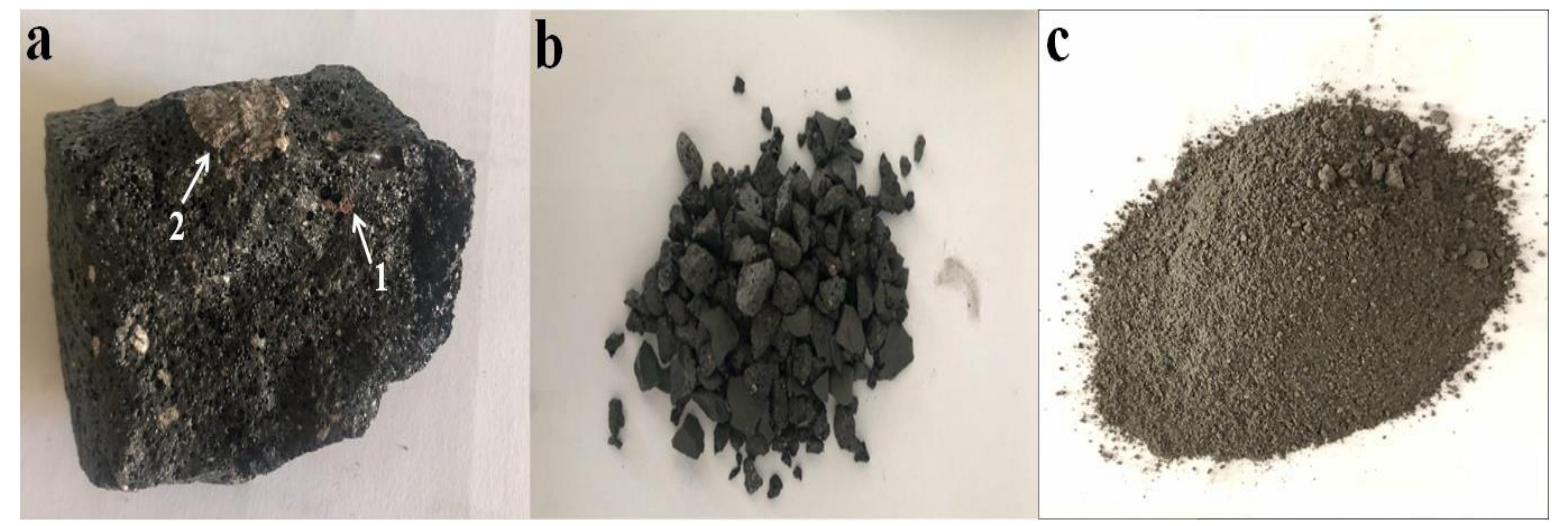

Şekil 1. a) Temin Edilen Kayaç Halindeki Anot Cürufu, b) Kırma Sonrası Anot Cürufu ve c) Öğütme Sonrası Toz Halindeki Anot Cürufu

Bilyeli değirmende öğütme ișlemlerinden sonra değirmenin haznesinde metalik bakır olduğu düșünülen farklı boyut ve şekilde parçacıklar elde edilmiştir. Ögütme sonrası elde edilen metal parçacıkların resmi ve bu parçacıklara ait XRD grafiği Şekil 2'de gösterilmiştir.

Şekil 2'deki XRD grafiğine göre, kayaç halindeki anot cürufunun bilyeli değirmende öğütme işlemlerinden sonra elde edilen metal parçacıkların metalik bakıra ait olduğu tespit edilmiştir. $\mathrm{Bu}$ sonuca göre, anot cüruflarında bulunan bakır metalinin bir kısmının ögütme esnasında bakırın süneklik özelliğinden yararlanarak mekanik ayırma yöntemi ile gerçekleştirilebileceği anlaşılmaktadır. Ancak, cüruf içerisinde çözünmüş halde bulunan ve/veya metalik

\subsection{Anot Cürufunun Karakterizasyonu}

Liç deneylerinde kullanılan anot cürufunun karakterizasyonu öğütme işleminden sonra elde edilen bakır parçacıkları elek yardımıyla ayrıldıktan sonra Şekil 1.c'de gösterilen toz halindeki anot cüruf kullanılarak gerçekleștirilmiştir. Anot cürufunun tane boyutu analizi Mastersizer marka tane boyutu analiz halde olmasına rağmen çok ince boyutlara sahip bakırın mekanik yolla ayrılması (geri kazanılması) mümkün olmamaktadır. Bu sebeple, bu çalışmada mekanik ayırma sonrasında düşük erime noktalı çözücü yardımıyla anot cürufu içerisindeki bakırın çözeltiye alınması amaçlanmıştır.

Düşük erime noktalı çözücünün hazırlanması için ticari olarak Merck firmasından satın alınan kolin klorür $\left(\mathrm{C}_{5} \mathrm{H}_{14} \mathrm{ClNO},>98 \%\right)$ ve Petkim firmasından satın alınan üre [CO $\left.\left(\mathrm{NH}_{2}\right)_{2},>99 \%\right]$ ticari olarak alındı ̆̆ şekilde (ilave bir saflaștırma yapılmaksızın) kullanılmıștır. Atomik Absorbsiyon spektroskometre (AAS) analizi için kullanılan standart çözeltiler (1000 mg.L-) ticari olarak Sigma Aldrich firmasında temin edilmiştir.

cihazı kullanarak belirlenmiştir. Toz halindeki anot cürufunun kimyasal analizi indüktif olarak eşleşmiş plazma - optik emisyon spektrometresi (ICP-OES), atomik absorpsiyon spektroskopisi (AAS) ve X-ışını floresans spektrometresi (XRF) cihazları yardımıyla gerçekleştirilmiştir. Kimyasal analizi gerçekleştirilen anot cürufunun mineralojik yapısının belirlenmesi için Bruker D8 Advance model X-Işını Kırınımı cihazı 
kullanılarak 15 - 85 derece arasındaki XRD grafikleri elde edilmiştir. Ayrıca, anot cürufunun detaylı mineralojik karakterizasyonu alan emisyonlu taramalı elektron mikroskobu (FE-SEM) cihazı yardımıyla gerçekleştirilmiştir. SEM analizlerinde, her hangi bir kaplama yapılmaksızın enerji dağılımlı X-Ray (EDS) spektroskopili Hitachi SU5000 model SEM cihazı kullanılmıştır.

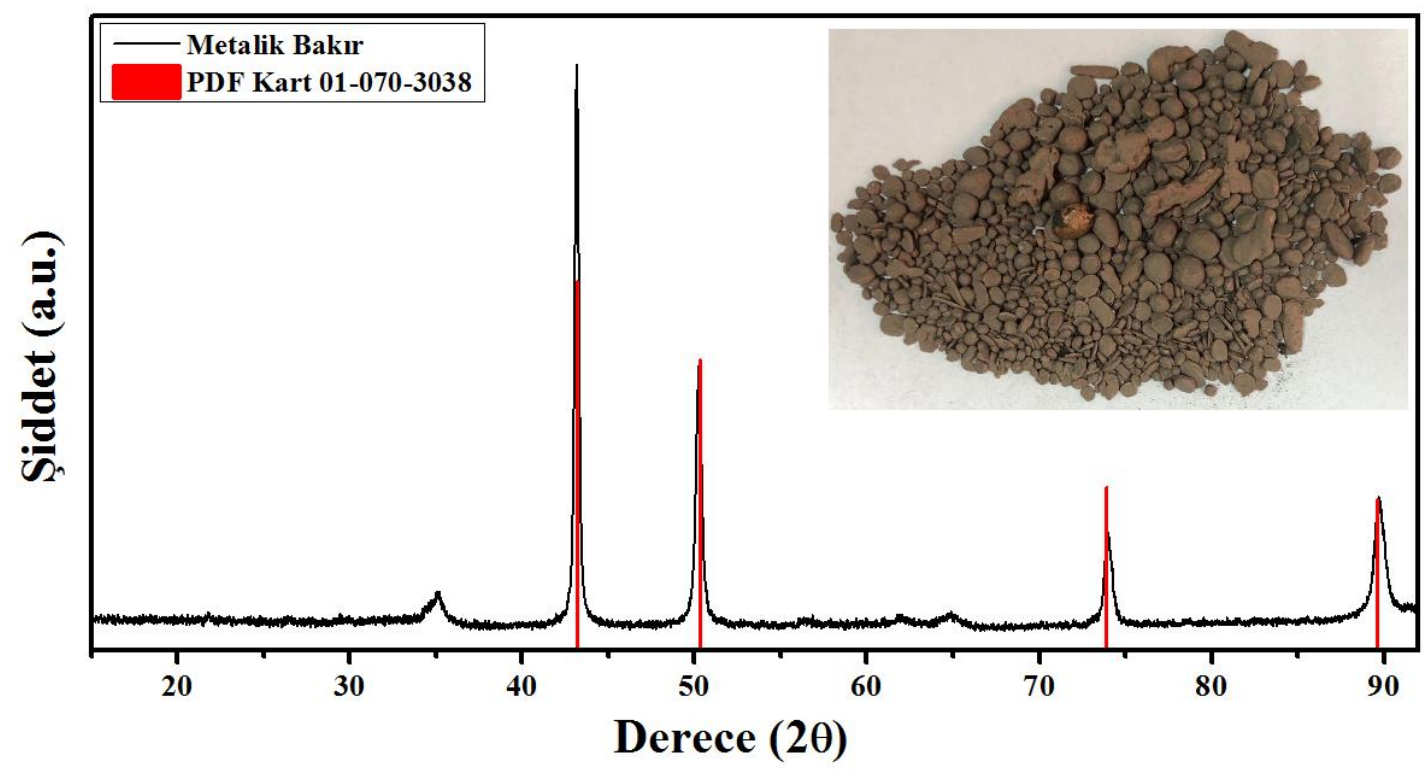

Şekil 2. Öğütme Sonrası Elde Edilen Metal Parçacıkların XRD Grafiği

\subsection{Düşük Erime Noktalı Çözücülerin Hazırlanması}

Ticari olarak satın alınan kolin klorür ve üre düșük erime noktalı çözücü hazırlamak için literatürde belirtildiği üzere (Abbott, Capper, Davies, McKenzie ve Obi, 2006b, Bakkar, 2014) ilave bir saflaştırma ve kurutma yapılmadan stokiyometrik olarak 1:2molar oranında renksiz ve homojen bir sıvı elde edilene kadar $80^{\circ} \mathrm{C}$ 'de karıștırılmıștır. Elde edilen sıvı soğutularak ağzı kapalı bir şişede muhafaza edilmiş ve daha sonra anot cürufundan bakır geri kazanımı için liç işlemlerinde kullanılmıştır. Düşük erime noktalı çözücülerin hazırlanması şematik olarak Şekil 3'de gösterilmiştir.

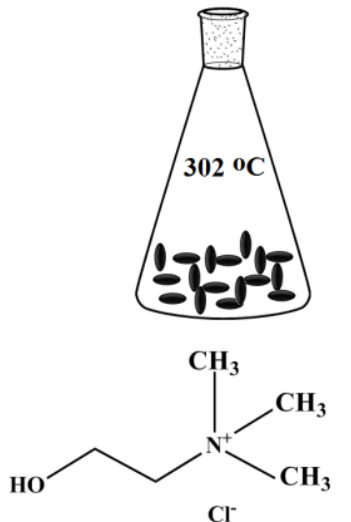

Kolin Klorür

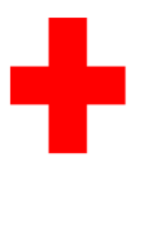<smiles>NC(N)=O</smiles>

Üre

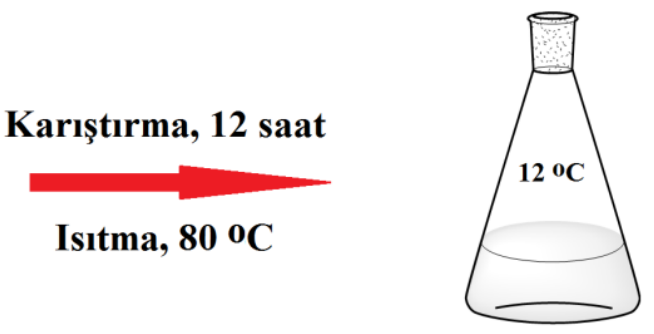

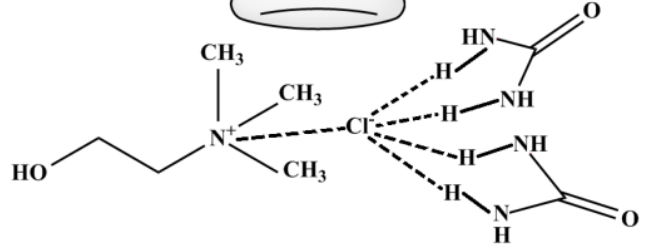

DES

Şekil 3. Düşük Erime Noktalı Çözücülerin Hazırlanmasının Şematik Gösterimi 


\subsection{Liç İşlemleri}

Anot cürufundan bakır geri kazanımı için gerçekleştirilen tüm liç deneyleri, ceketli ısıtıcı içerisine yerleştirilmiş üç boyunlu cam içerisinde gerçekleştirilmiştir. Isıtıcı $\pm 0,5{ }^{\circ} \mathrm{C}$ duyarlılığa sahip bir termokupl ile kontrol edilmiştir. Liç deneyleri sırasında, manyetik karıștırıcının hızı (600 devir/dk) ve düșük erime noktalı çözeltinin hacmi (50 mL) sabit değerlerde tutulmuştur.

Liç çalışmalarında, metal geri kazanımını liç kimyasalının konsantrasyonu, liç sıcaklığı, liç süresi, katı/sıvı oranı ve parçacık boyutu gibi birçok parametre etkilemektedir. (Guo, Pan, Xiao, Zhang ve Jiang, 2010) Bu çalışmada liç süresi (2-72 saat), liç sıcaklı̆̆ı (25 - 95 $\left.{ }^{\circ} \mathrm{C}\right)$ ve katı/sıvı oran $(1 / 10-1 / 40 \mathrm{~g} / \mathrm{mL})$ parametrelerinin anot cürufundan bakır geri kazanımı üzerine etkisi incelenmiştir. Düşük erime noktalı çözücülerin doğası gereği, iki bileşiğin belirli stokiometrik oranlarda karıştırılmasıyla elde edildiğinden, bu çalışma kapsamındaki deneylerde liç kimyasalının konsantrasyonu ChCl-üre 1:2molar oranı sabit tutularak diğer parametrelerin anot cürufundan bakır geri kazanımı üzerine etkisi incelenmiştir.

Liç deneylerinden sonra, katı-sıvı ayrımı vakum pompası yardımıyla gerçekleştirilmiştir ve süzme işlemi sonrası katı atık $\mathrm{HCl}$ asit çözeltisi ile yıkanmıştır. Elde edilen liç çözeltisi $0,1 \mathrm{M} \mathrm{HCl}$ ile kademeli olarak seyreltilmiştir. Uygun oranda seyreltilmiş liç çözeltisi
Perkin ElmerPinAccle 900T model atomik absorpsiyon spektroskopisi (AAS) cihazı kullanılarak analiz edilmiştir. Metal yüklü liç çözeltisindeki bakır miktarı AAS cihazı ile belirlenirken her bir analizde 3 değer alınmış ve geri kazanım oranı hesaplanırken bu değerlerin ortalaması kullanılmıştır. Bakır geri kazanım değeri Denklem 1 kullanılarak hesaplanmıștır.

$$
\% \text { Geri Kazanım }=\frac{C \times V \times S F}{m \times w} * 100
$$

burada C: AAS analizinden elde edilen değer (mg/L), V: liç sonrası elde edilen çözeltinin hacmi (L), SF: AAS analizi yapılan seyreltme miktarı, m: liç deneylerinde kullanılan anot çamurunun ağırlığı (g), w: Anot çamurunun ihtiva ettiği bakır elementinin oranıdır (mg/g).

\section{Bulgular Ve Tartışma}

\subsection{Anot Cürufunun Karakterizasyonu}

Liç deneylerinde kullanılan anot cürufunun fiziksel, kimyasal ve mineralojik karakterizasyonu öğütme sonrasında elek yardımıyla mekanik olarak ayrılan (Şekil 2) bakır parçacıklarının uzaklaştırılması sonrasinda toz halindeki anot cürufu (Şekil 1.c) kullanılarak gerçekleştirilmiştir. Liç deneylerinde kullanılan anot cürufunun SEM görüntüsü ile birlikte tane boyutu analizin sonucu Şekil 4'te gösterilmiştir.

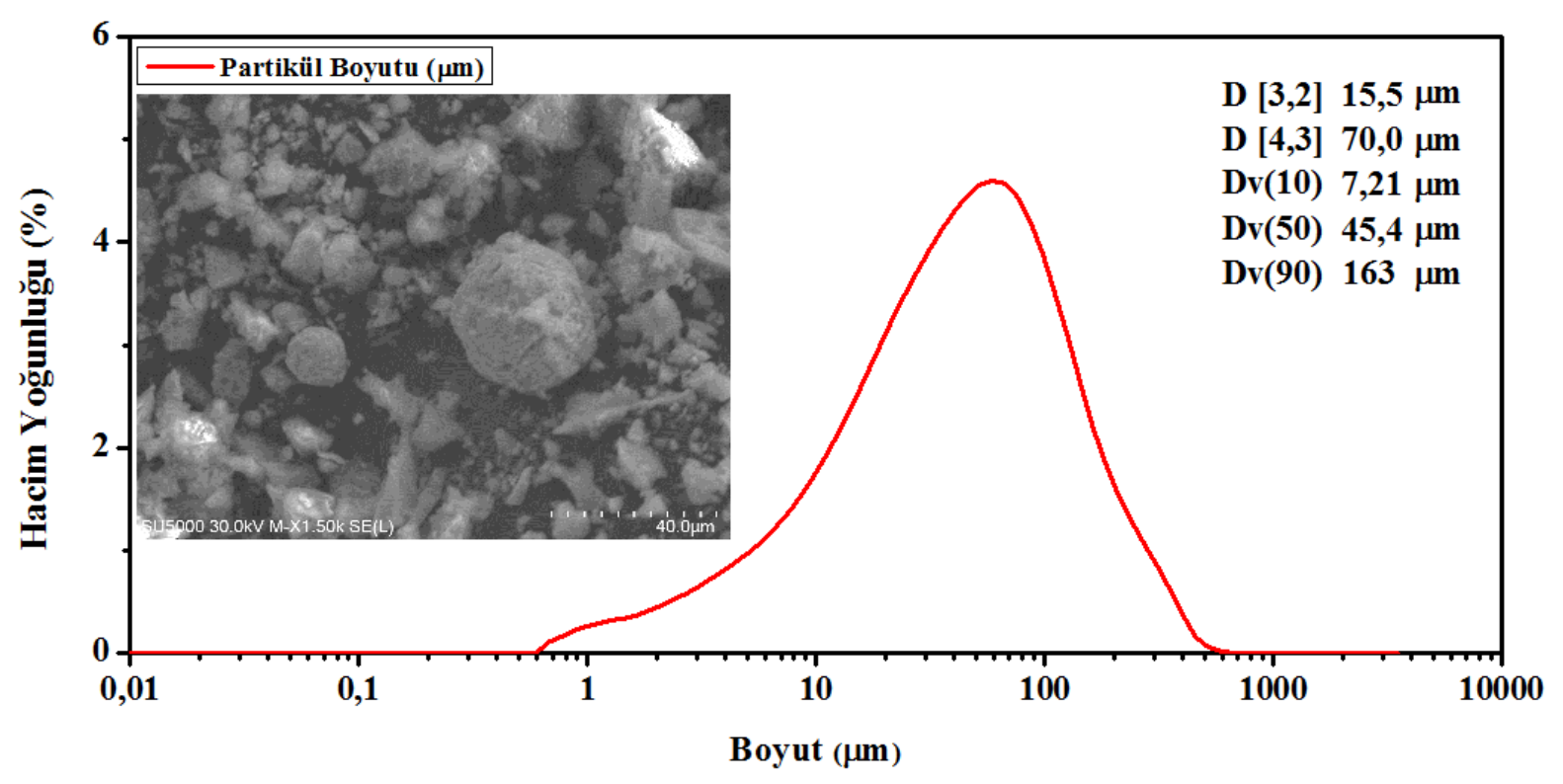

Şekil 4. Liç Deneylerinde Kullanılan Anot Cürufunun Tane Boyut Dağılımı 
Şekil 4'te SEM görüntüsüne göre, liç deneylerinde kullanılan anot cürufu farklı tane boyutlarına sahip olduğu anlașılmaktadır. Anot cürufunun partikül boyutu analizinden elde edilen $\operatorname{Dv}(90), \operatorname{Dv}(50)$ ve $\operatorname{Dv}(10)$ gibi ifadeler numunedeki toplam malzemenin hacminin sirasiyla \%90'ına, \%50'sine ve \%10'una kadar olan boyut dağılımındaki noktayı belirtir. Birçok araştırmacı cevherlerin tane boyutunu tanımlama da Dv(50) değerini kriter olarak belirtmektedir. $\mathrm{Bu}$ sebeple, deneysel çalışmalarda kullanılan anot cürufunun $\% 50$ 'sinin tane boyutunun $45,4 \mu \mathrm{m}$ veya daha küçük boyuta sahip olduğu söylenebilir.

Liç deneylerinde kullanılan anot cürufunun kimyasal analizi indüktif olarak eşleşmiş plazma-optik emisyon spektrometresi (ICP-OES) cihazı yardımıyla gerçekleştirilmiştir. Liç deneylerinde kullanılan anot cürufunun kimyasal analizi sonucu Tablo 1'de gösterilmiştir.

Tablo 1

Anot Cürufunun Kimyasal Analizi

\begin{tabular}{lr}
\hline Bileşen & Miktar (\% ă. $)$ \\
\hline $\mathrm{Cu}$ & 1,67 \\
$\mathrm{SiO}_{2}$ & 42,1 \\
$\mathrm{Fe}$ & 11,9 \\
$\mathrm{Sn}$ & 1,2 \\
$\mathrm{Zn}$ & 7,6 \\
$\mathrm{~Pb}$ & 2,1 \\
$\mathrm{CaO}$ & 10,6 \\
$\mathrm{Al}_{2} \mathrm{O}_{3}$ & 5,2 \\
$\mathrm{MgO}$ & 2,5 \\
\hline
\end{tabular}

Anot cürufunun 15-85 derecede elde edilen XRD grafiği Şekil 5'te gösterilmiştir. Bilyeli değirmende gerçekleştirilen öğütme işleminden sonra elde edilen anot cürufunun XRD analizine göre, liç deneylerinde kullanılan anot cürufunun farklı fazları bünyesinde ihtiva ettiği belirlenmiștir. Șekil 5'den de anlașılacağ üzere anot cürufunun ana yapısını manyetit ve $\mathrm{Ca}-\mathrm{Mg}$ elementlerini içeren fayalit fazları oluşturmaktadır. Ayrıca, XRD grafiğinde metalik bakırın fazının varlığının tespit edilmesi metalik bakırın ögütme aşamasında mekanik olarak tam ayrıştırılamadığının ve bir kısmının anot cürufu içerisinde kaldığını göstermektedir. Anot cürufu içerisinde bakır içerikli diğer bir yapının ise $\mathrm{Cu}$ $\mathrm{Zn}-\mathrm{S}$ kompleks yapısı olduğu tespit edilmiștir. Bu fazlarının yanı sıra anot cürufunun $\mathrm{SiO}_{2}, \mathrm{Al}_{2} \mathrm{O}_{3} . \mathrm{ySiO}_{2}$ ve $\mathrm{Pb}_{2} \mathrm{O}_{3}$ yapılarını da ihtiva ettiği belirlenmiştir.

Anot cürufunun detaylı mineralojik analizi SEM-EDS analizi ile gerçekleștirilmiştir. SEM ve EDS verilerinden elde edilen renkli haritalama yöntemi, araștırmacılar tarafından cevher ve atıklarda olası mineralojik yapıları belirlemek için sıklıkla kullanılmaktadır. Bu çalıșmada, renkli haritalama yöntemi ile ana elementlerin $(\mathrm{O}, \mathrm{Si}, \mathrm{Ca}$, $\mathrm{Fe}, \mathrm{Al}, \mathrm{Cu}, \mathrm{Zn}$ ve $\mathrm{Mg}$ ) dağılımı gösterilmiştir. Anot cürufuna ait farklı SEM görüntüleri ve EDS analizlerinin sonuçları Şekil 6 - 8'de gösterilmiştir.

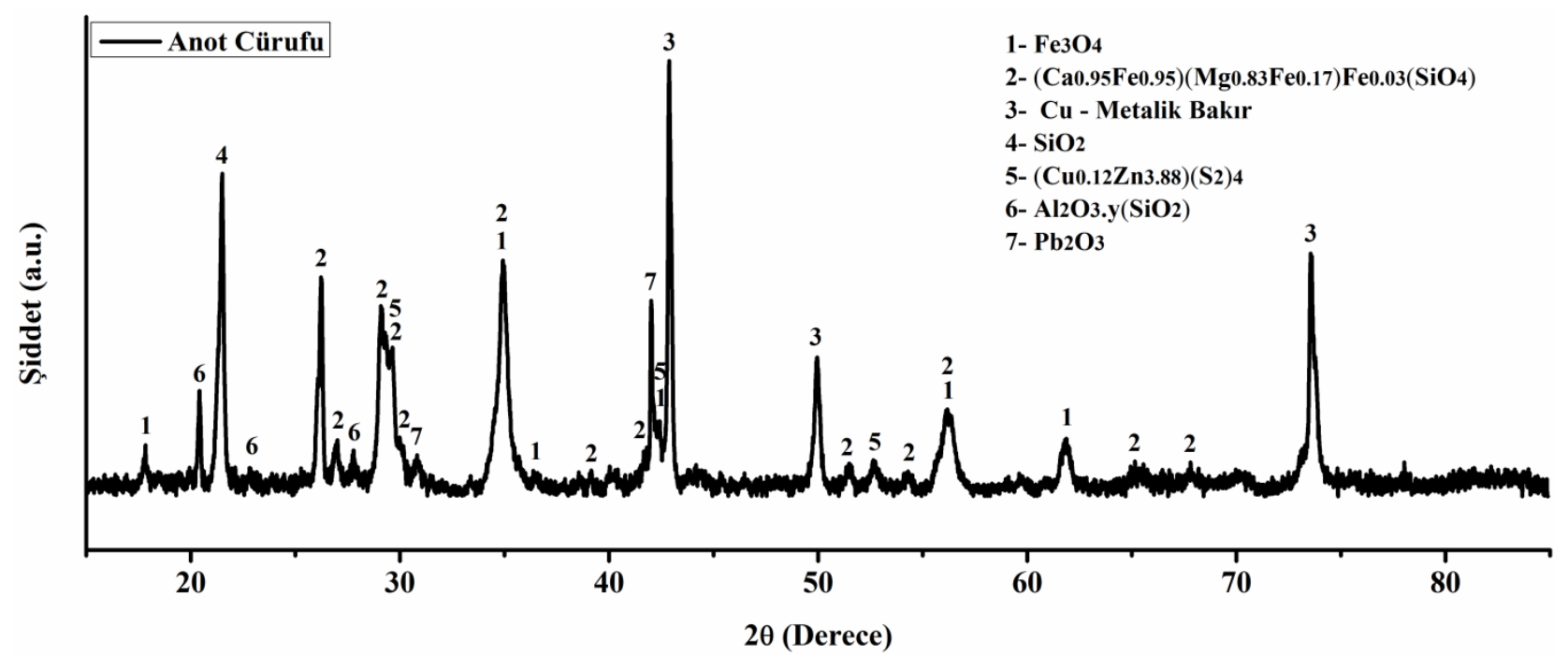

Şekil 5. Anot Cürufunun XRD Grafiği 


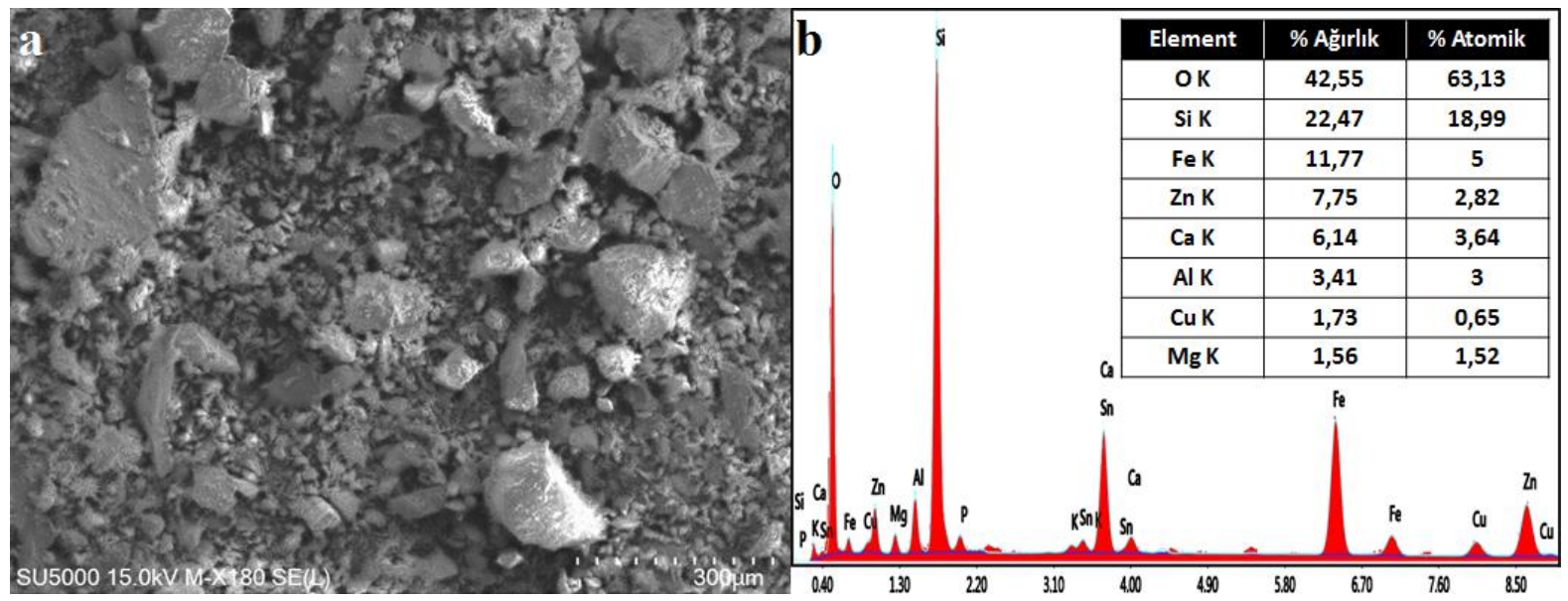

Şekil 6. Anot Cürufunun Seçili Alanı İçin SEM Görüntüsü ve EDS Analizi

Şekil 6'da görüldüğü üzere, anot cürufu farklı şekil ve boyutlarda birçok bileşeni içermektedir. Bu durum anot cürufunun boyut analizi sonucu ile benzerlik göstermektedir. Liç deneylerinde kullanılan anot cürufunun EDS analizi bölgesel olarak değişiklik göstermesi muhtemele olsa da Çizelge 1'de verilen kimyasal analiz ile uyum göstermektedir. Şekil 7.a'da anot cürufunun ihtiva ettiği iki farklı faz, Şekil7.b'de bu fazlara ait EDS sonuçları verilmiștir. Șekil 7'a'da 1 numara ile gösterilmiş yapının anot cürufunun ana fazlarından olan fayalit yapısına, 2 numara ile gösterilmiş olan yapının ögütme sonrası anot cürufu içerisinde kalan metalik bakıra ait olduğu tespit edilmiştir. Şekil 8'de anot cürufuna ait elementel haritalama yöntemi ile elde edilmiş SEM görüntüsü verilmiștir. Şekil 8'e göre \%99 saflı̆̆a sahip bakırın saflaştırılması sonrasında $\mathrm{Al}_{2} \mathrm{O}_{3}$ içerisinde sıkışmış bakır görülmektedir. Çalışmalarda kullanılan anot cürufunun SEM-EDS analizi anot cürufunun hem kimyasal hem de XRD analizi ile uyumlu olduğu tespit edilmiştir. XRD analizi ile tespit edilen spinel yapılar, metalik bakır ve $\mathrm{SiO}_{2}$ fazları SEM-EDS analizi ile de tespit edilmiștir. Fayalit tipi cüruflar üzerine yapılan önceki çalışmalar, cüruf içerisinde farklı partiküllerin, karbonca zengin kalıntıların ve oksitli yapıların da (CaO, $\mathrm{Al}_{2} \mathrm{O}_{3}$ vb.) bulanabileceğini göstermiştir. (Jalkanen, Vehviläinen ve Poijärvi, 2003; Mihailova ve Mehandijev., 2010; Liu ve diğ., 2015).

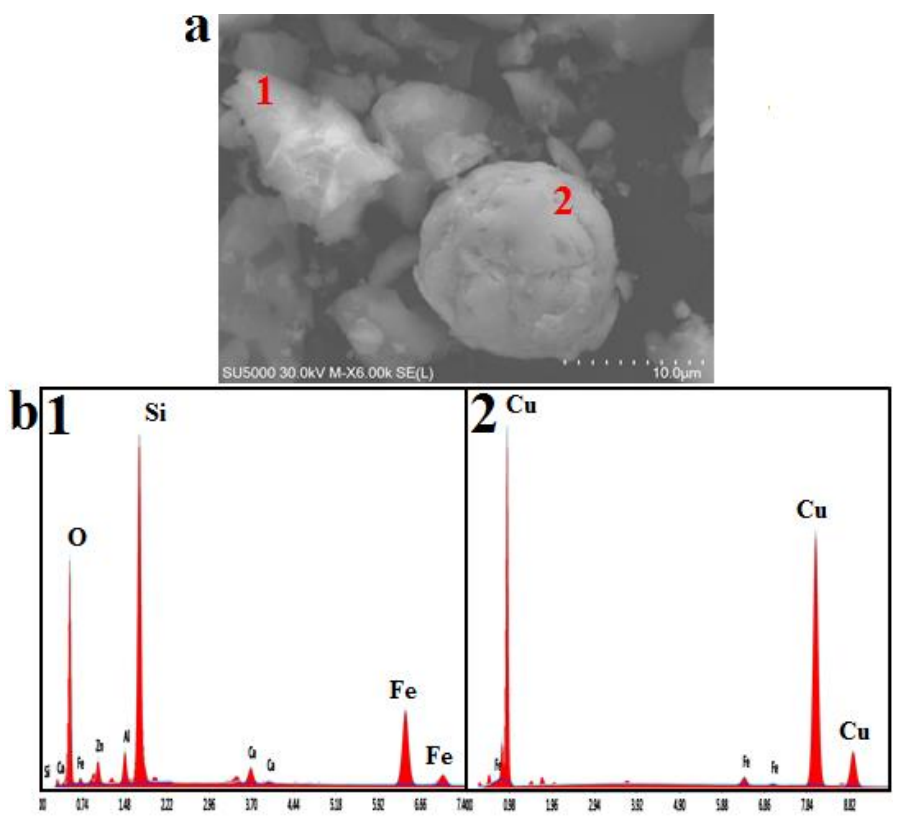

Şekil 7. Anot Cürufunun İhtiva Ettiği Fayalit Yapısı ve Metalik Bakır 


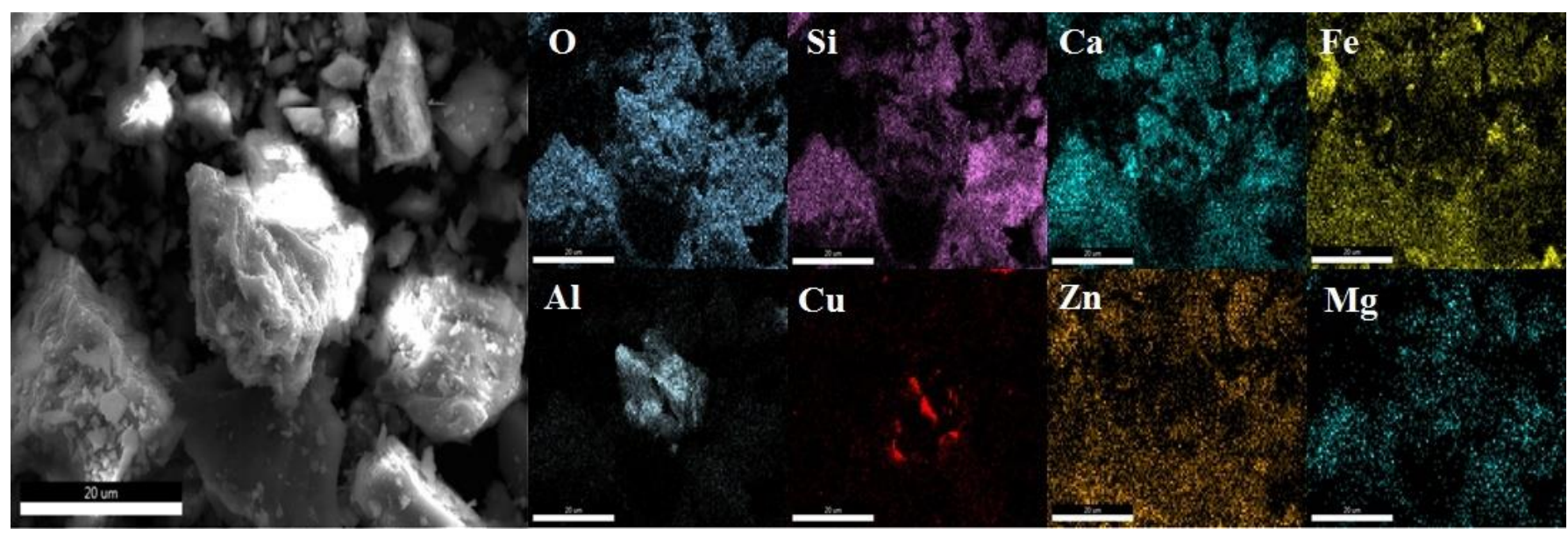

Şekil 8. Anot Cürufunun İhtiva Ettiği Alüminyum Oksit İçerisine Sıkışmış Bakır

\subsection{Liç Deneylerinin Bakır Geri Kazanımına Etkisi}

\subsubsection{Reaksiyon Süresinin Etkisi}

Anot cürufundan bakır geri kazanımı ve demir çözünürlüğü üzerine reaksiyon süresinin etkisi $2,8,16$,
32, 48 ve 72 saatlik liç deneyleri gerçekleştirilerek araștırılmıştır. Deneyler süresinde reaksiyon süresi dışındaki parametreler; $95{ }^{\circ} \mathrm{C}$ reaksiyon sıcaklığı, $1 / 20$ katı/sıvı oranı, $600 \mathrm{rpm}$ karıştırma hızında sabit tutulmuştur. Elde edilen deney sonuçları Şekil 9'da verilmiştir.

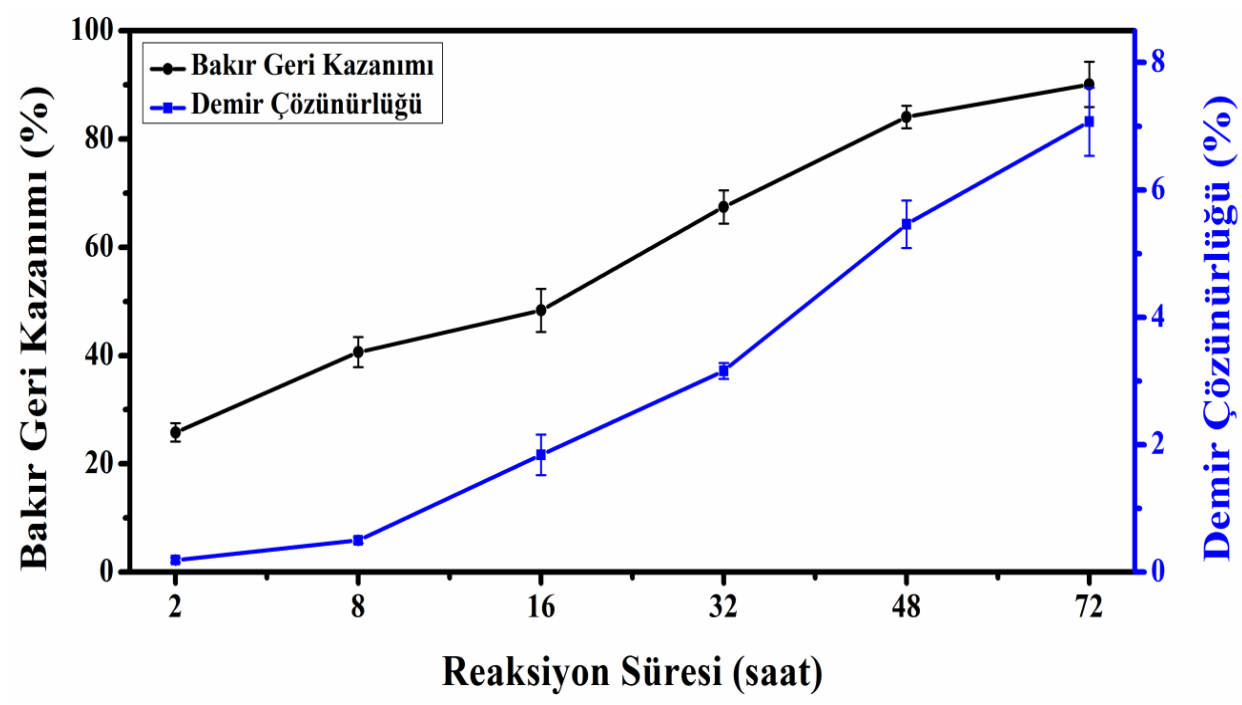

Şekil 9. Reaksiyon Süresinin Anot Cürufundan Bakır Geri Kazanımı ve Demir Çözünürlüğü Üzerine Etkisi

Șekil 9'da görüleceği üzere, anot cürufundan bakır geri kazanımı artan reaksiyon süresi ile birlikte kayda değer bir şekilde artmıştır. Kısa reaksiyon süresinde (2 saat) bakır geri kazanım değeri yaklaşık olarak \%26 iken, artan reaksiyon süresi birlikte 72 saatlik liç deneyinden sonra \%90,11'lik bakır geri kazanımı elde edilmiștir.
Deney sonuçlarına göre, 48 saatlik deney sonrası elde edilen bakır geri kazanım değeri ile 72 saatlik liç verimi karşılaştırıldığında artışın sadece \%5,81 olduğu gözlemlenmiş ve 48 saatlik liç deneyinden sonra bakır geri kazanımında sınırlı bir artış olduğu tespit edilmiştir. $\mathrm{Bu}$ sonuçlara göre DES sisteminde bakır 
ikincil atıklarından bakır geri kazanımı için 48 saatlik liç süresinin yeterli olduğu söylenebilir. Abbott ve ark., (2006a, 2006b) yaptığı çalışmada $\mathrm{CuO}$ ve $\mathrm{ZnO}$ gibi metal oksitlerden yüksek oranda bakır çözünürlüğü $50{ }^{\circ} \mathrm{C}$ çözünme sıcaklığında 60 saatlik işlem sonrası elde edilmiştir.

Diğer taraftan Şekil 9'dan da anlaşıldığı üzere, anot cürufundan demir çözünürlügünün çok düşük seviyede kaldığı ve liç süresiyle fazla değişmediği anlaşılmaktadır. Demirin asit ile yapılan işlemlere nazaran daha az çözünmesi, liç solüsyonlarından demirin uzaklaştırılması işlemlerini nispeten kolaylaştıracak, maliyet ve zaman açısından kazanç sağlayacaktır. Bu sonuçlara göre, anot cüruflarından bakırın yüksek oranla hidrometalurjik yöntemle geri kazanılması için DES’lerin kullanılabileceği görülmüştür. Düşük demir çözünürlüğü daha uzun liç süresi göz önüne alındığında, DES'ler anot cürufundan bakır geri kazanımı için iyi bir aday gibi görünmektedir.

\subsubsection{Reaksiyon Sıcaklığının Etkisi}

Anot cürufundan bakır geri kazanımı ve demir çözünürlüğü üzerine reaksiyon sıcaklığının etkisi 25, 50, 75 ve $95^{\circ} \mathrm{C}$ için, 48 saat reaksiyon süresi, $600 \mathrm{rpm}$ karıștırma hızı ve 1/20 katı/sıvı oranı şartları altında araştırılmıştır. Liç deneylerinin sonuçları Şekil 10'da gösterilmiştir.

Şekil 10'da görüldüğü üzere, anot cürufundan bakır geri kazanımı, DES çözücü sisteminde sıcaklığın artması ile birlikte sürekli olarak artmıștır. Yüksek sıcaklıklarda bakır geri kazanımındaki artış düşük kalmasına rağmen en yüksek bakır geri kazanım değeri $95{ }^{\circ} C^{\prime}$ lik liç ișleminde elde edilmiştir. Düşük sıcaklıklarda bakır geri kazanımı nispeten düşük kalsa da artan sıcaklıkla birlikte artmıștır ve en yüksek bakır geri kazanımı 95 ${ }^{\circ} C^{\prime}$ lik liç sıcaklığında \%84,30 olarak elde edilmiştir. Ayrıca, Şekil 10'da görüldüğü üzere, DES içerisinde anot cürufundan demir çözünürlügünün çok düşük seviyede (\%5,50 civarında) kaldığı ve artan liç sıcaklığı ile birlikte çok fazla değişmediği görülmektedir.

Abbott ve diğ., (2006b) belirtiği üzere DES içerisinde metal oksitlerin çözünürlüğünün etkili bir șekilde reaksiyon sıcaklığına bağlıdır. Kimyasal proseslerde sıcaklığın artışı ile hareketli taneciklerin çarpışma sayısının artacağı bilinmektedir. $\mathrm{ChCl} \mathrm{-} \mathrm{üre} \mathrm{(1:2)} \mathrm{ile}$ hazırlanan düşük erime noktalı çözücülerin sahip olduğu yüksek termal bozunma sıcaklığı (Delgadove diğ., 2018) nedeniyle yüksek sıcaklıklarda çalışma imkanı sunmaktadır. Çalışmada elde edilen sonuçlarla birlikte $\mathrm{ChCl} \mathrm{-} \mathrm{üre} \mathrm{ikilisiyle} \mathrm{hazırlanan} \mathrm{düşük} \mathrm{erime}$ noktalı çözücün yüksek sıcaklıklarda kullanımı ile metal geri kazanımının iyi oranlarda gerçekleştirilebileceği tespit edilmiştir.

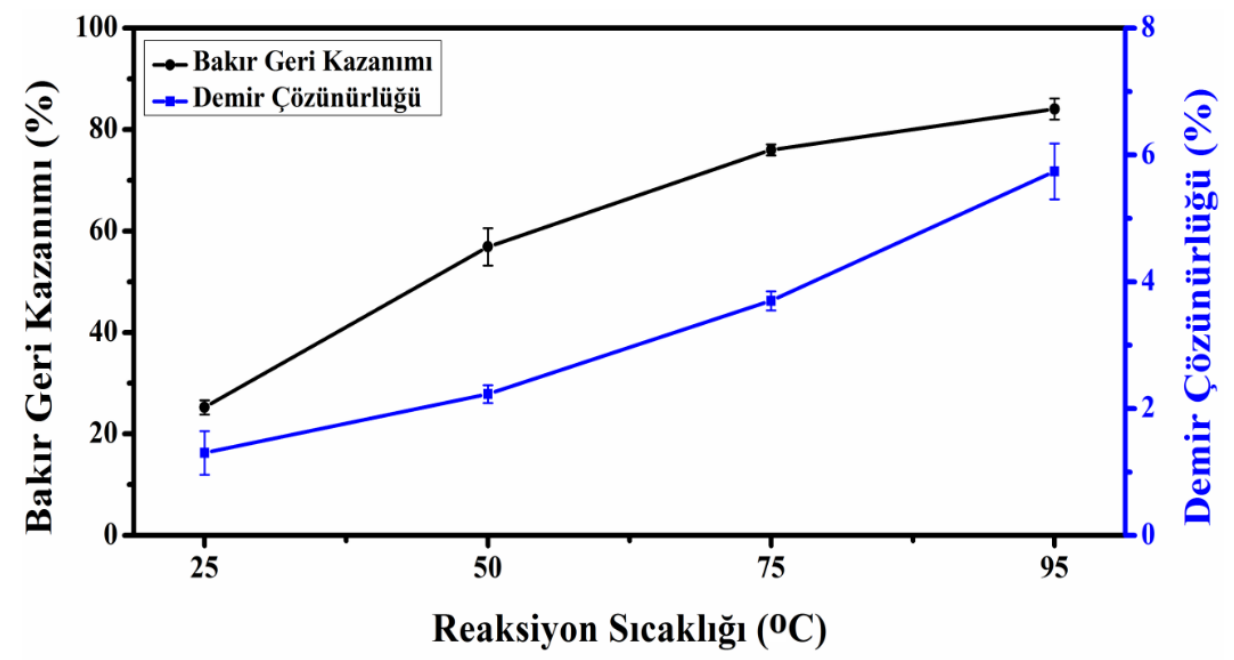

Şekil 10. Reaksiyon Sıcaklığın Anot Cürufundan Bakır Geri Kazanımı ve Demir Çözünürlüğü Üzerine Etkisi 


\subsubsection{Katı/Sıvı Oranın Etkisi}

Anot cürufundan bakır kazanımında katı/sıvı oranının etkisi incelenirken reaksiyon süresi 48 saat, karıștırma hızı $600 \mathrm{rpm}$ ve liç sıcaklığı $95^{\circ} \mathrm{C}$ olarak seçilmiştir. Bu deney şartlarında $100 \mathrm{ml}$ DES içerisine belirli katı/sıvı oranı elde edecek şekilde $(1 / 10,1 / 20,1 / 30,1 / 40$ için sirasıyla $10 \mathrm{gr}, 5 \mathrm{gr}, 3,33 \mathrm{gr}$ ve 2,5 gr) anot cürufu eklenerek deneyler gerçekleştirilmiştir. Deneysel sonuçları Şekil 11'de gösterilmiştir.

Şekil 11'de görüldügü üzere, bakır geri kazanımı azalan katı/sıvı oranı ile birlikte artmıștır. 1/10 katı/sıvı oranında yapılan liç işlemlerinden sonra bakır geri kazanım değeri \%41,17 olarak elde edilmiş ve bu noktadan sonra hızlı bir şekilde artmıştır. Azalan katı/sıvı oranına ile birlikte \%48,50'lik bir verim artışı sağlanmıș ve en yüksek bakır geri kazanım değeri 1/40 oranında yapılan liç işlemlerinden sonra \%89,67 olarak elde edilmiştir. 1/20 oranında yapılan liç işleminden sonra bakır geri kazanımında kayda değer bir artış olmamıştır. Bununla birlikte demir çözünürlüğü tüm deneylerde oldukça düşük seviyelerde kalmış ve azalan katı/sıvı oranı ile birlikte artmıștır. Bu deney şartlarında, ChCl-üre karışımı ile elde edilen DES çözeltisinin numune katılmadan önceki pH değeri 6,7 olarak okunmuştur. Anot cürufu ilavesi sonrasında deney süresince yapılan $\mathrm{pH}$ ölçümlerinde $\mathrm{pH}$ değeri kademeli olarak 8,6 değerine kadar yükselmiş ve deneyin tamamlanmasindan sonra yıkama suyu ile birlikte toplanan değerli liç çözeltisinin pH değeri 10,1 olarak ölçülmüștür.

\section{4. Çözünme Mekanizması}

Düşük erime noktalı çözücülerin elektron verme ve kabul etme özelliklerinden ötürü, metal oksitleri çözebilme yeteneklerine sahiptirler. Ancak, metal ve metal bileşenlerinin düşük erime noktalı çözücü içerisindeki çözünme mekanizmaları, geleneksel çözücülerdeki çözünme davranışları kadar iyi anlaşılmamıştır. Xie ve diğ., (2016) belirttiği üzere, kolin klorür ve üre ile hazırlanan düşük erime noktalı çözücü sisteminde, $\mathrm{Cl}^{-}$iyonları metal-oksijen bağını zayıflatarak ve metal merkezine üren bileșeninin oksijenini bağlayarak ürenin sıvı olarak görev yaptığı metal kompleks anyonlarının ( $\mathrm{MxClO}$.[üre]-) oluşumu teşvik eder. Ayrıca, önceki çalışmalarda belirtildiği üzere (Yang ve Reddy, 2014; Rao, ve diğ., 2019),metal kaynağından bağımsız olarak, $\mathrm{ChCl}$ ve üre ile hazırlan çözücü içerisinde metallerin çözünmesi sonrasında, nihai liç çözeltisi içerisinde metal kompleks anyonların oluştuğu bilinmektedir. Bu nedenle, anot cüruflarının düşük erime noktalı çözücü ile liç işleminden sonra, liç çözeltileri içerisinde [CuClO.üre] ${ }^{-}$kompleks anyonlarının meydana geldiği ifade edilebilir.Literatür bilgilerinin ışığı altında, bakırın kolin klorür ve üre ile hazırlanan düşük erime noktalı çözücü içinde çözünme reaksiyonu Denklem 2'deki gibi ifade edilebilir.

$$
\mathrm{Cu}+\mathrm{Ch}+\mathrm{Cl}-/ \text { üre } \rightarrow[\mathrm{CuClO} \text { üre }]^{-}+\mathrm{Ch}^{+}
$$

Araştırmacılar tarafından yapılan çalışmalarda (Abbott ve diğ, 2004; Bakkar ve Neubert, 2019), metal oksitler için yüksek çözünürlüklerin, organik asitler ve amidler ile ChCl'den oluşturulan DES'lerde elde edilebileceği gösterilmiştir, ancak asit bazlı DES'lerde (özellikle oksalik asit) demir oksitlerin nispeten daha yüksek çözünürlük gösterdiği belirtilmiștir. Metal oksitlerdeki metal-oksijen bağındaki iyonik/kovalent karakterin, malzemelerin fiziksel ve kimyasal özelliklerini etkilediği bilinmektedir (Lengent, 2004). Metal oksitlerdeki bu bağ yapısı farklı ortamlardaki çözünme karakteristiklerini de etkilemektedir. Abbott ve diğ. $(2004,2006)$ yaptıkları çalışmalarda, kullandıkları tüm düşük erime noktalı çözeltiler ( $\mathrm{ChCl}$ ile üre, etilen glikol, malonik asit, oksalik asit vb. karışımlar) içerisinde ZnO ve $\mathrm{CuO}$ gibi iyonik oksitlerin yüksek çözünürlük sergilemesine karşın $\mathrm{Al}_{2} \mathrm{O}_{3}$ gibi kovalent oksitlerin çözünmez olduğunu (veya çözünürlüğünün çok az olduğunu) vurgulamışlardır.

Metal ve oksijen arasında oluşan bağın, iki atomun elektronegatifliğindeki farka bağlı olduğu bilinmektedir. Demir elektronegatifliği 1.83 (kj/mol) iken oksijenin elektronegatif değeri $3.44(\mathrm{kj} / \mathrm{mol})$ 'dür. Bu durumda iki atom arasındaki elektronegatif fark 1,61 (kj/mol) olmaktadır. 0,4'ten daha düșük elektronegatiflik fark Polar Olmayan Kovalent Bağları, 0,4 - 1,7 arasındaki elektronegatiflik fark Polar Kovalent Bağları ve 1,7'den büyük elektronegatiflik fark ise İyonik Bağları temsil etmektedir. İki atom arasındaki elektronegatiflik fark 1,61 (kj/mol) olduğundan bağ karakteri polar olmasına rağmen iyonik bağ değerine çok yakındır. Bu sebeple, demir oksit için iyonik karaktere sahip polar kovalent bir bileşik tanımı yapılmaktadır (Lengent, 2004). Bu durum Abbott ve diğ. $(2004,2006)$ yaptıkları çalışma sonuçları ile paralellik göstererek kovalent bağ yapısına sahip bileşiklerin ChCl-Üre çözeltisi içerisinde çözünmediği (veya az çözündüğü) sonucunu desteklemektedir.

Yukarıda bahsedilen deneysel veriler, kolin klorür ve üre temelli liç işleminin bakır endüstrisi için etkili bir hidrometalurjik süreç olma potansiyelini gösterdiği söylenebilir. Ayrıca, Satlewal, Agrawal, Bhagia, Sangoro ve Ragauskas (2018) ifade ettiği üzere, düşük erime noktalı çözücülerin hazırlanmaları kimyasal reaksiyonlar sonucu olmadığı bunun yerine zayıf hidrojen bağı ile oluştuğundan, imidazolyum temelli iyonik sıvılara nazaran geri dönüşümleri daha kolaydır. Birçok alanda olduğu gibi hidrometalurji alanında da yeni bir çözücü olan düşük erime noktalı çözücüler, 
toksik olmamaları nedeniyle insan sağlığına zarar vermeyen çözücü olarak kullanımı yakın gelecekte yaygınlaşacaktır. Ayrıca, ucuz olmaları sebebiyle endüstriyel boyutta kullanılarak ekonomik fayda sağlaması da beklenmektedir. Tüm bunların yanında, düşük erime noktalı çözücülerle yapılan işlemler su içermeyen (solvo-metalurjik)süreçler olduğundan dolayı su kaynaklarının korunmasında yarar sağlaması düşünebilir.

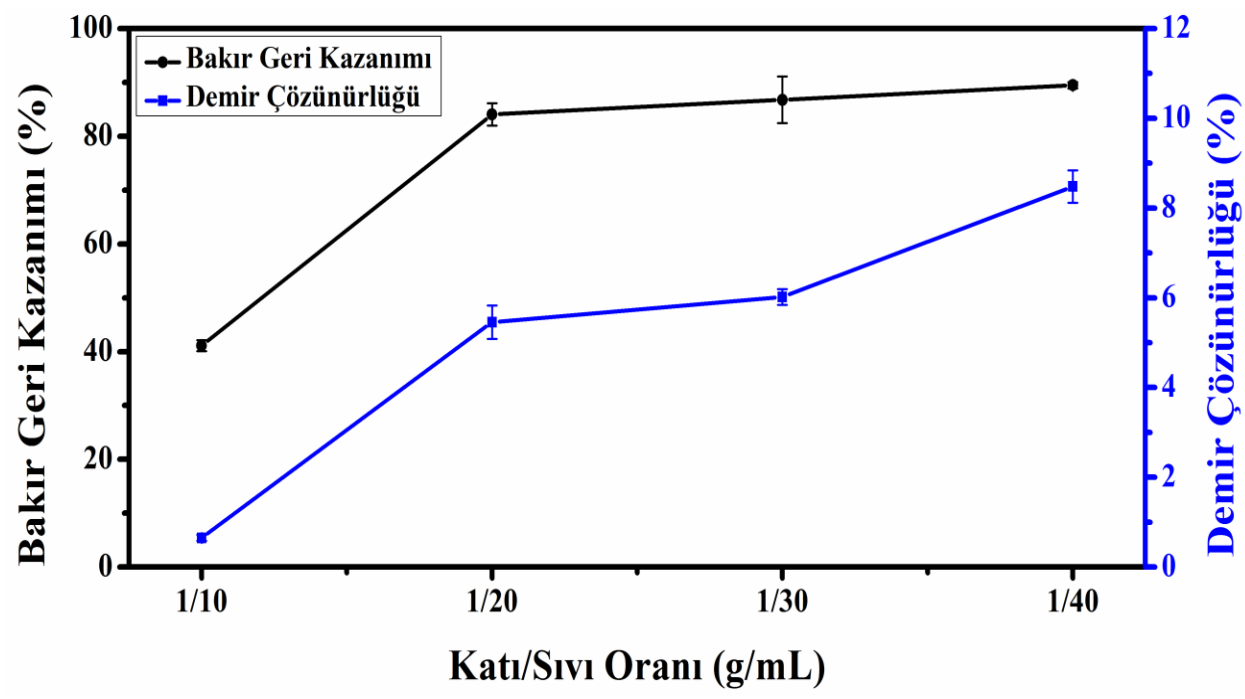

Şekil 11. Katı/Sıvı Oranın Anot Cürufundan Bakır Geri Kazanımı ve Demir Çözünürlüğü Üzerine Etkisi

\section{Sonuçlar}

$\mathrm{Bu}$ çalışmada geleneksel çözücülerin yerine daha az maliyetli, insan ve çevre sağlı̆̆ına zararları olmayan düşük erime noktalı çözücüler kullanılarak anot cüruflarından bakır geri kazanımı araștırılmıștır. Liç ve karakterizasyon analizlerinden önce gerçekleştirilen ögütme işlemi ile anot cürufundan metalik bakırın mekanik olarak geri kazanılabileceği tespit edilmiştir. Elde edilen metalik bakırın ayrılmasından sonra yapılan kimyasal analize göre, anot cürufunun $\% 1,67 \mathrm{Cu}, \% 11,9$ $\mathrm{Fe}, \% 7,6 \mathrm{Zn}$ ve \%2,1 Pb içerdiği tespit edilmiştir. Anot cürufunun mineralojik analizine göre, anot cürufunun ana yapısının manyetit ve Ca-Mg elementlerini içeren fayalit fazlarının oluşturduğu tespit edilmiştir. Ayrıca, öğütme sonrasında elde edilen metalik bakırın anot cürufu içerisinde kaldığı ve bakır içerikli bir diğer yapının $\mathrm{Cu}-\mathrm{Zn}-\mathrm{S}$ kompleks yapısı olduğu tespit edilmiștir. $\mathrm{Bu}$ yapılarla birlikte, $\mathrm{SiO}_{2}, \mathrm{Al}_{2} \mathrm{O}_{3} \cdot \mathrm{xSiO}_{2}$ ve $\mathrm{Pb}_{2} \mathrm{O}_{3}$ yapılarının da anot cürufu bünyesinde olduğu belirlenmiştir.

Liç deneylerinde kullanılan düşük erime noktalı çözücülerin kolin klorür ve üre bileşenlerinin 1:2molar oranında karıştırılmasıyla elde edilmiştir. $\mathrm{ChCl}$ ve üre ile yapılan liç deneylerinden sonra, anot cürufundan en yüksek bakır geri kazanım değeri 72 saatlik reaksiyon süresi, $95{ }^{\circ} \mathrm{C}$ reaksiyon sıcaklığı ve $1 / 20 \mathrm{katı} / \mathrm{sıvı}$ oranında yapılan liç deneyinden sonra yaklaşık \%90 olarak elde edilmiştir. Liç deneylerinde, demir çözünürlüğünün oldukça düşük seviyelerde kaldığı gözlemlenmiş ve bu durumun liç çözeltilerinden bakır geri kazanım süreçlerinde demirin olumsuz etkilerini bertaraf edebileceği beklenmektedir. $\mathrm{Bu}$ çalışma, pirometalurjik yöntemlerle bakır üretiminde ortaya çıkan anot cürufları gibi atıkların düşük erime noktalı çözücüler ile değerlendirilmesinin mümkün olduğunu göstermekte olup hem ülke ekonomisi hem de çevre sağlığı için faydalı sonuçlar ortaya çıkarmaktır.

\section{Teşekkür}

Bu çalışmanın yapılmasını 17-M-18 proje numarası ile destekleyen Karamanoğlu Mehmetbey Üniversitesi Bilimsel Araştırma Projeleri Koordinatörlüğü'ne teşekkür ederiz.

\section{Araştırmacıların Katkısı}

$\mathrm{Bu}$ araştırmada; Mehmet Ali Topçu deneylerin yapılması, deney sonuçlarının analiz edilmesi, makalenin yazılması; Aydın Rüşen deney tasarımlarının yapılması, numunelerin temini, makalenin genel kontrolünün yapılması konularında katkı sağlamışlardır.

\section{Çıkar Çatışması}

Yazarlar tarafından herhangi bir çıkar çatışması beyan edilmemiștir. 


\section{Kaynaklar}

Abbott, A. P., Capper, G., Davies, D.L., Rasheed, R. K., \&Tambyrajah, V. (2003). Novel solvent properties of choline chloride/urea mixtures. Chemical Communications, (1), 70-71. doi: https://doi.org/10.1039/B210714G

Abbott, A. P., Boothby, D., Capper, G., Davies, D. L., \& Rasheed, R. K. (2004). Deep eutectic solvents formed between choline chloride and carboxylic acids: versatile alternatives to ionic liquids. Journal of the American Chemical Society, 126(29), 9142-9147.doi: https://doi.org/10.1021/ja048266j

Abbott, A. P., Capper, G., Davies, D. L., Rasheed, R. K., \&Shikotra, P. (2005). Selective extraction of metals from mixed oxide matrixes using choline-based ionic liquids. Inorganic Chemistry, 44(19), 6497-6499.doi: https://doi.org/10.1021/ic0505450

Abbott, A. P., Capper, G., Davies, D. L. \&Shikotra, P. (2006). Processing metal oxides using ionic liquids. Mineral Processing and Extractive Metallurgy, 115(1), 15-18 doi: https://doi.org/10.1039/C0GC00716A

Abbott, A. P., Capper, G., Davies, D. L., McKenzie, K. J. \&Obi, S. U. (2006). Solubility of metal oxides in deep eutectic solvents based on choline chloride. Journal of Chemical \& Engineering Data, 51(4), 1280-1282. doi: https://doi.org/10.1021/je060038c

Abbott, A. P., Collins, J., Dalrymple, I., Harris R. C., Mistry, R., Qiu, F., ...\& Wise, R. W. (2009). Processing of electric arc furnace dust using deep eutectic solvents. Australian Journal of Chemistry, 62(4), 341-347. doi: https://doi.org/10.1071/CH08476

Agrawal, A., Kumari, S. \& Sahu, K. K. (2009). Iron and copper recovery/removal from industrial wastes: A review. Industrial \& Engineering Chemistry Research, 48(13), 6145-6161. doi: https://doi.org/10.1021/ie900135u

Arslan, C. \&Arslan, F. (2002). Recovery of copper, cobalt, and zinc from copper smelter and converter slags. Hydrometallurgy, 67(1-3), 1-7. doi: https://doi.org/10.1016/S0304386X(02)00139-1

Bakkar, A. (2014). Recycling of electric arc furnace dust through dissolution in deep eutectic ionic liquids and electrowinning. Journal of Hazardous Materials, 280, 191-199. doi: https://doi.org/10.1016/ j.jhazmat.2014.07.066

Bakkar, A., \& Neubert, V. (2019). Recycling of cupola furnace dust: Extraction and electrodeposition of zinc in deep eutectic solvents. Journal of Alloys and Compounds, 771, 424-432. doi: https://doi.org/10.1016/j.jallcom.2018.08.246
Banza, A. N., Gock, E. \&Kongolo, K. (2002). Base metals recovery from copper smelter slag by oxidising leaching and solvent extraction. Hydrometallurgy, 67(1-3), 63-69. doi: https://doi.org/10.1016/S0304-386X(02)00138-X

Boyrazlı, M., Altundogan, H. S., \&Tümen, F. (2006).Recovery of metals from copper converter slag by leaching with $\mathrm{K}_{2} \mathrm{Cr}_{2} \mathrm{O}_{7}-\mathrm{H}_{2} \mathrm{SO}_{4}$. Canadian Metallurgical Quarterly, 45(2), 145-152.doi: https://doi.org/10.1179/cmq.2006.45.2.145

Chen, M. S., Han, Z. R. \& Wang, L. Z. (2012). Recovery of valuable metals from copper slag by hydrometallurgy. Advanced Materials Research, 402, 35-40. doi: $\underline{\text { https://doi.org/10.4028/ }}$ www.scientific.net/AMR.402.35

Dai, Y., Van Spronsen, J., Witkamp, G. J., Verpoorte, R. \&Choi, Y. H. (2013).Natural deep eutectic solvents as new potential media for green technology. AnalyticaChimicaActa, 766, 61-68.doi: https://doi.org/10.1016/j.aca.2012.12.019

Delgado-Mellada, N., Laribba, M., Navarro, P., Rigual, V., Ayuso, M., Garcia, J. \& Rodriguez, F., (2018). Thermal stability of choline chloride deep eutectic solvents by TGA/FTIR-ATR analysis.Journal of Molecular Liquids, 260, 37 - 43. doi: https://doi.org/10.1016/ j.molliq.2018.03.076

Dong, T., Hua, Y., Zhang, Q. \& Zhou, D. (2009). Leaching of chalcopyrite with Brønsted acidic ionic liquid. Hydrometallurgy, 99(1-2), 33-38. doi: https://doi.org/10.1016/j.hydromet.2009.06.001

Gorai, B., \& Jana, R. K. (2003). Characteristics and utilisation of copper slag-a review. Resources, Conservation and Recycling, 39(4), 299-313. doi: https://doi.org/10.1016/S0921-3449(02)00171-4

Guo, Z. H., Pan, F. K., Xiao, X. Y., Zhang, L. \& Jiang, K. Q. (2010). Optimization of brine leaching of metals from hydrometallurgical residue. Transactions of Nonferrous Metals Society of China, 20(10), 20002005. doi: https://doi.org/10.1016/S10036326(09)60408-8

Huang, J., Chen, M., Chen, H., Chen, S. \& Sun, Q. (2014).Leaching behaviour of copper from waste printed circuit boards with Brønsted acidic ionic liquid. Waste Management, 34(2), 483-488. doi: https://doi.org/10.1016/j.wasman.2013.10.027

Jalkanen, H., Vehviläinen, J., \&Poijärvi, J. (2003). Copper in solidified copper smelter slags. Scandinavian Journal of Metallurgy, 32(2), 65-70. doi: https://doi.org/10.1034/j.16000692.2003.00536.x

Lee, J., Kim, S. \& Shin, D. (2015). Electrolytic recovery of $\mathrm{Fe}$ from $\mathrm{Cu}$ smelter slag in nitric acid solution. Journal of Applied Electrochemistry, 45(3), 
281-288. doi: https://doi.org/10.1007/s10800-015$\underline{0797-0}$

Lenglet, M. (2004). Iono-covalent character of the metal-oxygen bonds in oxides: a comparison of experimental and theoretical data. Active and Passive Electronic Components, 27, 1-60 doi: https://doi.org/10.1080/0882751031000116142

Li, Y., Papangelakis, V. G. \&Perederiy, I. (2009). High pressure oxidative acid leaching of nickel smelter slag: Characterization of feed and residue. Hydrometallurgy, 97(3-4), 185193.doi:https://doi.org/10.1016/j.hydromet.2009. $\underline{03.007}$

Liu, W., Rao, S., Wang, W., Yang, T., Yang, L., Chen, L. \& Zhang, D. (2015). Selective leaching of cobalt and iron from cobalt white alloy in sulfuric acid solution with catalyst. International Journal of Mineral Processing, 141, 8-14. doi: https://doi.org/10.1016/ j.minpro.2015.06.002

Mihailova, I. \&Mehandjiev, D. (2010). Characterization of fayalite from copper slags. Journal of the University of Chemical Technology and Metallurgy, 45(3), 317326. Erișim adresi: https://dl.uctm.edu/journal/ node/j20103/12 Irena Mihailova 317-326.pdf

Nadirov, R. K., Syzdykova, L. I., Zhussupova, A. K. \&Usserbaev, M. T. (2013). Recovery of value metals from copper smelter slag by ammonium chloride treatment. International Journal of Mineral Processing, 124, 145-149. doi: https://doi.org/10.1016/j.minpro.2013.07.009

Paiva, A., Craveiro, R., Aroso, I., Martins, M., Reis, R. L. \&Duarte, A. R. C. (2014). Natural deep eutectic solvents-solvents for the 21st century. ACS Sustainable Chemistry \& Engineering, 2(5), 10631071.doi: https://doi.org/10.1021/sc500096j

Rao, S., Zou, X., Wang, S., Lu, Y., Shi, T., Hsu, H. Y., ... Lu, X. (2019). Electrodeposition of $\mathrm{Ni}-\mathrm{Cu}$ alloy films from nickel matte in deep eutectic solvent. Materials Chemistry and Physics, 232, 6-15. doi: https://doi.org/10.1016/j.matchemphys.2019.04.052

Roy, S., Sarkar, S., Datta, A., \& Rehani, S. (2016). Importance of mineralogy and reaction kinetics for selecting leaching methods of copper from copper smelter slag. Separation Science and Technology, 51(1), 135-146. doi : https://doi.org/10.1080/01496395.2015.1073309

Rüşen, A. \&Topcu, M. A. (2017).Optimization of gold recovery from copper anode slime by acidic ionic liquid. Korean Journal of Chemical Engineering, 34(11), 2958-2965. doi: https://doi.org/10.1007/s11814-017-0200-4
Rüşen, A. \&Topcu, M.A. (2017). Investigation of Various Metal Recoveries from Zinc Plant Leach Residue by Choline-Chloride Agent. Current Physical Chemistry, 7(4), 273-280. doi: https://doi.org/ 10.2174/1877946807666170808120341

Satlewal, A., Agrawal, R., Bhagia, S., Sangoro, J. \&Ragauskas, A. J. (2018). Natural deep eutectic solvents for lignocellulosic biomass pretreatment: Recent developments, challenges and novel opportunities. Biotechnology Advances, 36 (8), 20322050. doi: https://doi.org/10.1016/ j.biotechadv.2018.08.009

Topçu, M. A., Rüşen, A. \&Derin, B. (2019). Minimizing of copper losses to converter slag by a boron compound addition. Journal of Materials Research and Technology, 8(6), 6244-6252. doi: https://doi.org/10.1016/j.jmrt.2019.10.018

Turan, M. D., Sarıkaya, M., Sarı, A.Z., Haxhiaj, A., Depci, T., Demirarslan A. \&Nizamoğlu, H. (2017) Investigating and optimization of copper extraction from chalcopyrite concentrate with hydrogen peroxide in presence of acetic acid. Chemical Physical Chemistry, 7(4), 267 - 272. doi: https://doi.org/10.2174/ $\underline{1877946807666170808114115}$

Whitehead, J. A., Zhang, J., Pereira, N., McCluskey, A. \&Lawrance, G. A. (2007).Application of 1-alkyl-3methyl-imidazolium ionic liquids in the oxidative leaching of sulphidic copper, gold and silver ores. Hydrometallurgy, 88(1-4), 109-120.doi: https://doi.org/10.1016/j.hydromet.2007.03.009

Xiang, J., Huang, Q., Lv, X. \&Bai, C. (2017). Multistage utilization process for the gradient-recovery of $\mathrm{V}, \mathrm{Fe}$, and $\mathrm{Ti}$ from vanadium-bearing converter slag. Journal of Hazardous Materials, 336, 1-7. Doi : https://doi.org/10.1016/j.jhazmat.2017.04.060

Xie, X., Zou, X., Lu, X., Zheng, K., Cheng, H., Xu, Q. \&Zhou, Z. (2016). Voltammetric study and electrodeposition of $\mathrm{Cu}$ from $\mathrm{CuO}$ in deep eutectic solvents. Journal of The Electrochemical Society, 163(9), 537 - 543. Doi : https://doi.org/10.1149/2.1241609jes

Yang, H. \& Reddy, R. G. (2014). Fundamental studies on electrochemical deposition of lead from lead oxide in 2: 1 urea/choline chloride ionic liquids. Journal of The Electrochemical Society, 161(10), D586. doi: https://doi.org/10.1149/2.1161410jes

Zhang, Q., Vigier, K. D., Royer, S. \& Jerome, F. (2012). Deep eutectic solvents: syntheses, properties and applications. Chemical Society Reviews, 41, 71087146. doi: https://doi.org/10.1039/C2CS35178A 